Fourth International Conference on Sustainable Construction Materials and Technologies http://www.claisse.info/Proceedings.htm

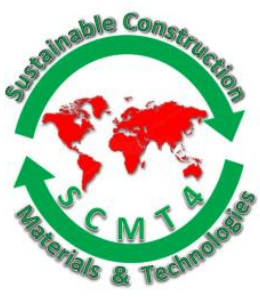

SCMT4

Las Vegas, USA, August 7-11, 2016

\title{
Experimental Study of Structural Concrete Strength in Massive Concrete Elements Made of New High-Volume BFS Cement
}

\author{
Kohsuke Ishizeki $^{1 \mathrm{a}}$, Tetsushi Kanda ${ }^{1 \mathrm{~b}}$, Kazuhisa Yoda ${ }^{1 \mathrm{c}}$, Masarou Kojima ${ }^{2}$, and Toshiaki \\ Mizobuchi $^{3}$
}

${ }^{1}$ Building Construction and Materials Group, Kajima Technical Research Institute, 2-19-1, Tobitakyu, Chofu-City,Tokyo 182-0036 Japan. ${ }^{1 a}$ Email: <ishizeki@kajima.com>, ${ }^{1 b}$ Email: <kandat@kajima.com>,

${ }^{1 c}$ Email: <yodak@kajima.com>

${ }^{2}$ Takenaka Research and Development Institute, Takenaka Corporation, 1-5-1, Otsuka, Inzai-City, Chiba Pref., 270-1395 Japan. ${ }^{2}$ Email: < kojima.masarou@takenaka.co.jp>

${ }^{3}$ Department of Civil and Environmental Engineering, Faculty of Engineering and Design, Hosei University, 2-33, Ichigaya-tamachi, Shinjyuku-ku., Tokyo 162-0843 Japan.

${ }^{3}$ Email: <mizobuchi@hosei.ac.jp>

\begin{abstract}
ECM concrete refers to those with high-volume blast furnace slag capable of reducing environmental burden, and its strength in structure was experimentally verified for practical applications. Prediction of concrete strength in structures was studied in terms of strength of specimens subjected to simplified adiabatic curing and cores sampled from imitated columns under standard and summer climatic conditions. Regarding the strength of ECM concrete in structures, development of strength with ages was found to be reproducible, as a function of effective age, using an existing formula in a satisfactory manner. The strength correction value ${ }_{28} S_{91}$ of ECM concrete in structure, which is defined as a difference between 28-day strength of standard curing specimens and 91-day strength in structure, was equal to or smaller than the standard value specified in JASS5-2009.
\end{abstract}

\section{INTRODUCTION}

Environmental burden of concrete materials is largely originated from cement clinker, hence effective reduction of environmental burden can be made when clinker is replaced with admixture from industrial by-products [JCI 2008, 2010]. Among such materials, ground blast furnace slag is widely used for instance in RCD concrete for dam constructions where technology capable of reducing clinker amount as low as 10 percent was proposed [Sakata et al. 2010]. However, concrete using such binder system exhibited several drawbacks including low early-age strength, large slump loss at fresh state and large autogenous shrinkage. A new concrete with high-volume ground blast furnace slag cement (hereafter denoted as ECM cement) capable of solving above-mentioned problems has been developed by the authors. ECM cement comprises high volume ground blast furnace slag to reduce clinker content as low as 30 percent of the total binder amount and higher amount of $\mathrm{SO}_{3}$ to improve early-age strength development and shrinkage behavior [Yonezawa et al. 2010]. Because energy saving and $\mathrm{CO}_{2}$ reduction of concrete with ECM cement are 40 
and 65 percent of portland cement concrete respectively, and ECM cement can meet the Japanese Industrial Standard of Blast furnace slag cement Type C, further application is anticipated in terms of environmental burden reduction and practicability.

Concretes with ECM cement (hereafter denoted as ECM concrete) can be put into practice when its strength in structure is assured. However, existing data for the influence of early-stage high temperature histories due to hydration heat liberation on the column and beam strength of concrete with a cement belonging to blast furnace slag cement type $\mathrm{C}$ are very scarce. This study mainly focused on ECM concrete manufactured in a working ready-mixed concrete plant. Strength of specimens subjected to simplified adiabatic curing and core specimens sampled from the full-scaled elements were investigated and discussed on the development of concrete strength in structures.

Table 1. Test Parameters and Levels

\begin{tabular}{|c|c|c|c|c|}
\hline \multirow{2}{*}{ Climatic condition } & \multicolumn{3}{|c|}{ Test parameter } \\
\cline { 2 - 4 } & W/C & Cement type & Specimen type & Placement date \\
\hline \multirow{3}{*}{ Standard } & 0.55 & & & \\
& 0.45 & - & Simplified adiabatic, & Core, Standard \\
& 0.38 & & & Three levels \\
\hline Summer & - & ECM, BFSC Type B & & \\
\hline
\end{tabular}

Table 2. Combinations of Test Parameters and Levels

\begin{tabular}{|c|c|c|c|c|c|}
\hline Climatic condition & Notation & $\mathrm{W} / \mathrm{C}$ & Cement & Specimen & Placement \\
\hline \multirow{3}{*}{ Standard } & ECM-55 & 0.55 & \multirow{6}{*}{ ECM } & $\begin{array}{l}\text { SAC*2 } \\
\text { STD }\end{array}$ & \multirow{3}{*}{4 April } \\
\hline & ECM-45 & 0.45 & & $\begin{array}{c}\text { Core, SAC } \\
\text { STD }\end{array}$ & \\
\hline & ECM-38 & 0.38 & & \multirow{3}{*}{$\begin{array}{l}\text { SAC } \\
\text { STD }\end{array}$} & \\
\hline \multirow{4}{*}{ Summer } & ECM-S1 & 0.42 & & & 21 July \\
\hline & ECM-S2*1 & 0.42 & & & 7 August \\
\hline & ECM-S3 & 0.42 & & \multirow{2}{*}{$\begin{array}{c}\text { Core, SAC } \\
\text { STD }\end{array}$} & \multirow{2}{*}{22 August } \\
\hline & BB & 0.44 & BFSC-B & & \\
\hline
\end{tabular}

*1 Only ECM-S2 was mixed in the laboratory

*2 SAC: Simplified adiabatic curing, STD: Standard curing

Table 3. Concrete Materials

\begin{tabular}{|c|c|c|c|c|}
\hline & Notation & Type & Character $\left(\mathrm{g} / \mathrm{cm}^{3}\right)$ & Note \\
\hline \multirow{2}{*}{ Cement } & \multirow{2}{*}{$\mathrm{C}$} & ECM cement $* 3$ & Density: 2.98 & - \\
\hline & & BFSC-Type B*4 & Density: 3.04 & - \\
\hline \multirow{2}{*}{$\begin{array}{c}\text { Fine } * 1 \\
\text { aggregate }\end{array}$} & S1 & Pit sand (Chiba) & SSD density: $\quad * 52.58$ & - \\
\hline & S2 & Crushed limestone (Tochigi) & SSD density: 2.65 & - \\
\hline \multirow{2}{*}{$\begin{array}{l}\text { Coarse } * 2 \\
\text { aggregate }\end{array}$} & G1 & Crushed limestone 2005 (Saitama) & SSD density: 2.70 & - \\
\hline & G2 & Crushed limestone 2005 (Tochigi) & SSD density: 2.70 & - \\
\hline \multirow{3}{*}{ Admixture } & \multirow{3}{*}{ Ad } & Prototype $1 * 6$ & Density: 1.08 & Standard \\
\hline & & Prototype $2 * 7$ & Density: 1.09 & \multirow{2}{*}{ Summer } \\
\hline & & Superplasticizer for BB & Density: 1.09 & \\
\hline
\end{tabular}

*1 mixed use with S1:S2=5:5, bulk density: $2.62 \mathrm{~g} / \mathrm{cm} 3$

*2 mixed use with G1:G2=5:5, bulk density: $2.70 \mathrm{~g} / \mathrm{cm} 3$

*3 Adoptable to blast furnace slag cement type $C$,

Blaine value of ground blast furnace slag: 4000

*4 Blast furnace slag cement type $B$

*5 SSD: Saturated surface-dry condition

*7 Standard type superplasticizer dedicated for ECM

*8 Retarding type superplasticizer dedicated for ECM 
Table 4. Mix Proportions

\begin{tabular}{|c|c|c|c|c|c|c|c|c|c|c|}
\hline \multirow{2}{*}{ Climatic condition } & \multirow{2}{*}{ Notation } & \multirow{2}{*}{$\mathrm{W} / \mathrm{C}$} & \multirow{2}{*}{$\begin{array}{l}\mathrm{s} / \mathrm{a} \\
(\%)\end{array}$} & \multicolumn{6}{|c|}{ Unit amount $\left(\mathrm{kg} / \mathrm{m}^{3}\right)$} & \multirow{2}{*}{$\operatorname{Ad}(\mathrm{C} \times \%)$} \\
\hline & & & & $\mathrm{W}$ & $\mathrm{C}$ & $\mathrm{S} 1$ & S2 & G1 & $\mathrm{G} 2$ & \\
\hline \multirow{3}{*}{ Standard $* 1$} & ECM-55 & 0.55 & 48.2 & 172 & 313 & 429 & 429 & 474 & 474 & 0.9 \\
\hline & ECM-45 & 0.45 & 46.0 & 175 & 389 & 391 & 391 & 474 & 474 & 0.9 \\
\hline & ECM-38 & 0.38 & 43.2 & 179 & 471 & 350 & 350 & 474 & 474 & 0.9 \\
\hline \multirow[t]{2}{*}{ Summer*1*2 } & $\begin{array}{l}\text { ECM-S1 } \\
\text { ECM-S2 } \\
\text { ECM-S3 }\end{array}$ & 0.42 & 44.0 & 178 & 424 & 366 & 366 & 481 & 481 & 0.9 \\
\hline & BB & 0.44 & 42.6 & 186 & 428 & 281 & 421 & 487 & 487 & 0.8 \\
\hline
\end{tabular}

*1 Slump: $18 \mathrm{~cm}$, Air content: $4.5 \%$

*2 Nominal strength: 36

Table 5. Cement Quality

\begin{tabular}{|c|c|c|c|c|}
\hline \multirow{2}{*}{ Quality } & \multicolumn{2}{|r|}{ ECM } & \multicolumn{2}{|r|}{$\mathrm{BB}$} \\
\hline & Measured & Standard*1 & Measured & Standard*2 \\
\hline $\begin{array}{l}\text { Density } \\
\left(\mathrm{g} / \mathrm{cm}^{3}\right)\end{array}$ & 2.98 & - & 3.04 & - \\
\hline $\begin{array}{l}\text { Specific surface area } \\
\qquad\left(\mathrm{cm}^{2} / \mathrm{g}\right)\end{array}$ & 4170 & $\geqq 3300$ & 3800 & $\geqq 3000$ \\
\hline $\begin{array}{l}\text { Setting } \\
\text { (h-min) }\end{array}$ & $\begin{array}{c}\text { Initial 3-55 } \\
\text { Final 6-10 }\end{array}$ & $\begin{array}{c}\text { Initial } 60 \mathrm{~min} \geq \\
\text { Final } \leq 10 \mathrm{~h}\end{array}$ & $\begin{array}{c}\text { Initial 3-03 } \\
\text { Final 4-21 }\end{array}$ & $\begin{array}{c}\text { Initial } 60 \mathrm{~min} \geq \\
\text { Final } \leq 10 \mathrm{~h}\end{array}$ \\
\hline Stability & Good & Good & Good & Good \\
\hline $\begin{array}{l}\text { Compressive strength } \\
\left(\mathrm{N} / \mathrm{mm}^{2}\right)\end{array}$ & $\begin{array}{l}18.2 \text { (3-day) } \\
31.5 \text { (7-day) } \\
52.0 \text { (28-day) }\end{array}$ & $\begin{array}{l}\geq 7.5 \text { (3-day) } \\
\geq 15.0 \text { (7-day) } \\
\geq 40.0 \text { (28-day) }\end{array}$ & $\begin{array}{l}21.6 \text { (3-day) } \\
37.1 \text { (7-day) } \\
64.6 \text { (28-day) }\end{array}$ & $\begin{array}{l}\geq 10.0 \text { (3-day) } \\
\geq 17.5 \text { (7-day) } \\
\geq 42.5 \text { (28-day) }\end{array}$ \\
\hline $\mathrm{MgO}(\%)$ & 5.0 & $\leq 6.0$ & 3.4 & $\leq 6.0$ \\
\hline $\mathrm{SO}_{3}(\%)$ & 3.6 & $\leq 4.5$ & 2.2 & $\leq 4.0$ \\
\hline Ig. Loss (\%) & 0.3 & $\leq 5.0$ & 1.3 & $\leq 5.0$ \\
\hline Chloride ion (\%) & 0.006 & - & 0.11 & - \\
\hline
\end{tabular}

*1 Japanese Industrial Standard JIS R 5211 type C

*2 Japanese Industrial Standard JIS R 5211 type B

Table 6. Test Items

\begin{tabular}{|c|c|c|}
\hline Test & Specimen & Testing method \\
\hline Fresh test & - & Slump, air content, temp. \& unit mass \\
\hline Bleeding test & $\phi 250 \times 285 \mathrm{~mm}$ & JIS A 1123 \\
\hline Compressive strength for STD & $\phi 100 \times 200 \mathrm{~mm}$ & JIS A 1108 at 28, 56 and 91 days \\
\hline Compressive strength for SAC & $\phi 100 \times 200 \mathrm{~mm}$ & $\begin{array}{c}\text { JIS A 1108, JASS5T-606 at 28, 56 } \\
\text { and 91 days }\end{array}$ \\
\hline Compressive strength for core & $\phi 100 \times 200 \mathrm{~mm}$ & $\begin{array}{c}\text { JIS A 1107, JASS5T-605 at 28, 56 } \\
\text { and 91 days }\end{array}$ \\
\hline Concrete temp. & IC+SAC*1 & 7 days after mixing \\
\hline
\end{tabular}

*1 IC+SAC: Imitated column and simplified adiabatic curing 
Table 7. Combination of Tests

\begin{tabular}{|c|c|c|c|c|c|c|}
\hline $\begin{array}{l}\text { Climatic } \\
\text { condition }\end{array}$ & Notation & Fresh & Bleeding & SAC strength & Core strength & Concrete temp. \\
\hline \multirow{3}{*}{ Standard } & ECM-55 & \multirow{3}{*}{ ○ } & \multirow{3}{*}{ o } & \multirow{3}{*}{ ○ } & - & SAC \\
\hline & ECM-45 & & & & 0 & $\mathrm{IC}+\mathrm{SAC}$ \\
\hline & ECM-38 & & & & - & SAC \\
\hline \multirow{4}{*}{ Summer } & ECM-S1 & \multirow{4}{*}{0} & \multirow{4}{*}{ - } & \multirow{4}{*}{0} & - & SAC \\
\hline & ECM-S2 & & & & - & SAC \\
\hline & ECM-S3 & & & & 0 & IC+SAC \\
\hline & BB & & & & $\circ$ & $\mathrm{IC}+\mathrm{SAC}$ \\
\hline
\end{tabular}

\section{EXPERIMENTAL PLAN}

Parameter and combination. Factors affecting the concrete strength in structure were studied using ECM concrete manufactured in a working ready-mixed concrete plant. Experiments comprised two series representing standard and summer climatic conditions as shown in table 1 and were executed in April and July-August respectively. Test parameters were water-cement ratio (W/C), cement type, specimen type, placement date and mixing scale. For a nominal strength ranging from 21 to 36, W/C of concrete to be placed under standard climate condition was adopted 0.55, 0.45 and 0.38. Cement type included ECM cement and blast furnace slag cement type B for concrete to be placed under summer climate condition. Specimens were subjected to two types of curing, simplified adiabatic curing and standard curing, and those sampled from structures as core specimens. For specimens placed under summer climatic condition, test was repeated for three times to check influences of placement date, and one of three mixing was performed in a laboratory.

Combinations of the test parameters and levels are shown in table 2. A total seven combinations, including three combinations for standard climatic condition and four combinations for the summer climatic condition, were tested. Effects of water-cement ratio on the concrete strength in structure were examined through the tests under standard climatic condition, while under the summer climatic condition, variations in concrete strength in structure by placement date as well as comparison with the strength of blast furnace slag cement type B concrete were intended.

Material, mix proportion and mixing. Materials used and their mix proportions are shown in table 3 and 4. Both ECM cement and blast furnace slag cement type B met the requirements specified in JIS R 5211 (table 5). Clinker content of ECM cement was approx. $30 \%$ and, as an $\mathrm{SO}_{3}$ source, anhydride was added to an upper limit of $4 \%$. As shown in table 5, compressive strength of ECM cement satisfies the requirements for blast furnace slag cement type B at material ages of 3, 7 and 28 days, implying that strength development may pose smaller concern than expected. Quality of fine and coarse aggregates was the same as those normally used in the ready-mixed concrete plant producing ECM concrete. Chemical admixture used was a prototype developed for ECM concrete capable of improving slump loss that is a major concern for concrete with high-volume blast furnace slag.

Mix proportions, as shown in table 4, were determined according to trial mixings performed in a laboratory of the ready-mixed concrete plant. For a targeted slump of $18 \mathrm{~cm}$ and air content of $4.5 \%$, mixes for standard climatic condition were designed to have a slump of $19 \pm 2.5 \mathrm{~cm}$ and air content of $4.5 \pm 1.5 \%$ taking account of loss during transportation. Referring to the results of the standard climatic condition, mixes for summer climatic condition and a nominal strength of 36 were designed to have a slump of $18 \pm 2.5 \mathrm{~cm}$ and air content of $4.5 \pm 1.5 \%$. Notation BB refers to a standard mix of the ready-mixed concrete plant to have the same nominal strength and slump of the ECM concrete. Mixing time both in laboratory and plant was $40 \mathrm{~s}$ after all the materials were introduced to a biaxial forced mixer. 
Test items and methods. Test items and test methods are shown in table 6 and combinations of test are shown in table 7. In this Table, all cases of tests for fresh state were performed immediately after mixing. As the major emphasis of this study, strength of concrete in structure was estimated with two types of specimen including those cored from the imitated column and those subjected to simplified adiabatic curing [AIJ 2009]. In addition, compressive strength of specimens subjected to standard curing was also determined to estimate the correction value for concrete strength in structure, ${ }_{28} S_{91}$ (hereafter denoted as ${ }_{28} S_{91}$ value). Imitated column specimens as shown in table 7 were produced only with mixes ECM-45, ECMS3 and BB. Core specimens and simplified adiabatic curing specimens were sampled according to JASS5T605 and JASS5T-606 respectively. Core specimens were sampled from imitated column specimen, which was thermally insulated at upper and bottom surfaces to have a condition similar to the central part of a column [AIJ 2009]. An example of the imitated column and positions of core sampling are shown in figure 1. Temperature histories of the imitated column were measured at three points comprising the center of specimen and exterior and interior coring positions. Specimens subjected to simplified adiabatic curing were arranged in a thermally insulated form as shown in figure 2 and temperatures inside of specimen were recorded.

\section{EXPERIMENTAL RESULTS}

Test results of fresh concrete and concrete temperatures. Test results of fresh concrete are shown in table 8. Slump and air content were over all within a controlled range except for ECM-S2 that was mixed in a laboratory under the summer climatic condition showing slightly larger slump and air content. Although

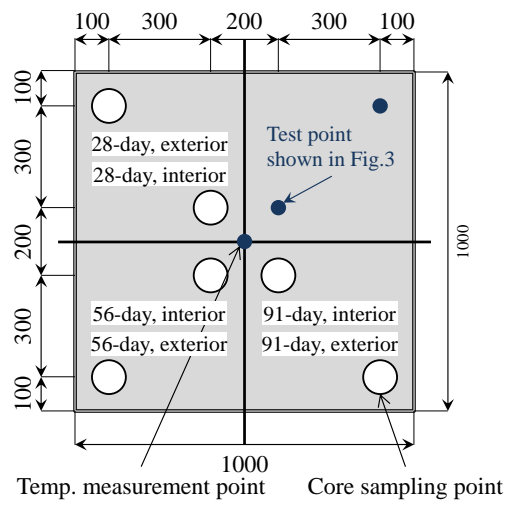

Plan view

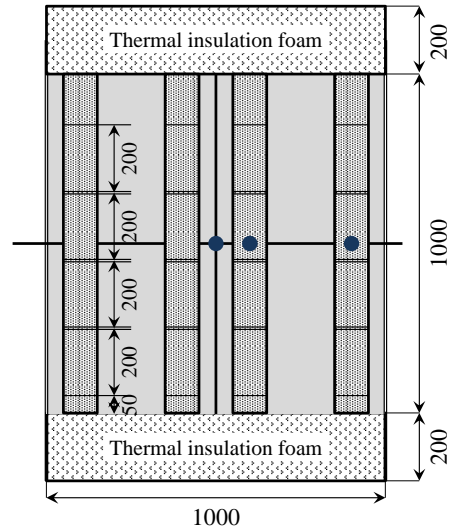

Cross section

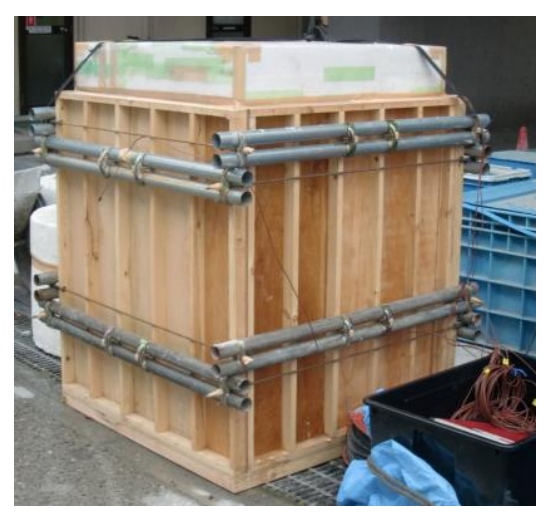

An example of specimen

Figure 1. Imitated Column Specimen

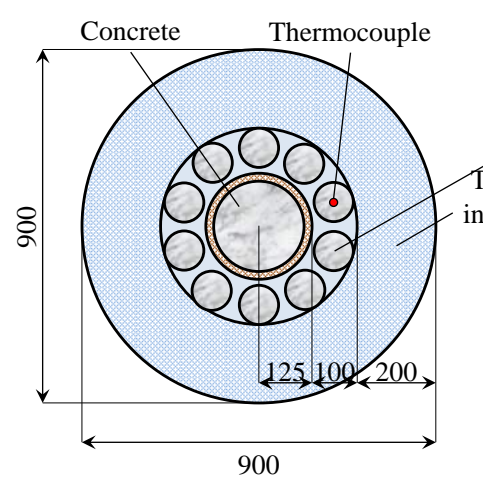

Simplified adiabatic curing chamber

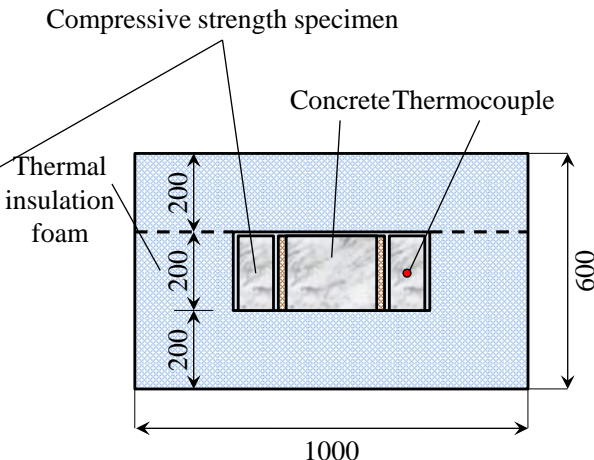

1000

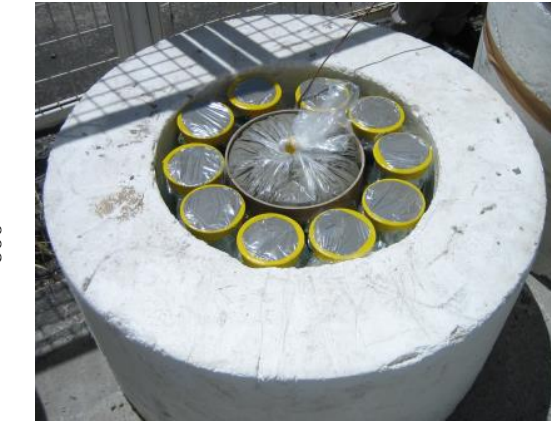

Specimen setting

Figure 2. Simplified Adiabatic Curing Chamber 
larger bleeding was concerned for ECM concrete due to its small clinker content, measured bleeding was as low as $0.3 \mathrm{~cm}^{3} / \mathrm{cm}^{2}$ which corresponds to the upper limit of a sound concrete.

Temperature histories of concrete in structure are shown in figure 3 where those of imitated column are of interior coring positions as shown in figure 1. Among temperature histories of specimens placed under standard climatic condition and subjected to simplified adiabatic curing, maximum temperature of specimen with a water-cement ratio of 0.38 was 10 degree higher than those with a water-cement ratio of 0.55 as shown in figure 3(a). Maximum temperature of nearly $70^{\circ} \mathrm{C}$ was recorded in an imitated column specimen ECM-S3 placed under summer condition while it was still 10 degree lower than that of BB with the same nominal strength. ECM concrete showed lower temperature increase than that of $\mathrm{BB}$ and thus may be more advantageous than BB in terms of thermal cracking control. Difference in temperature history among ECMS1, S2 and S3 with simplified adiabatic curing was approx. 10 degree at maximum temperature reflecting the difference in outdoor temperatures at placement.

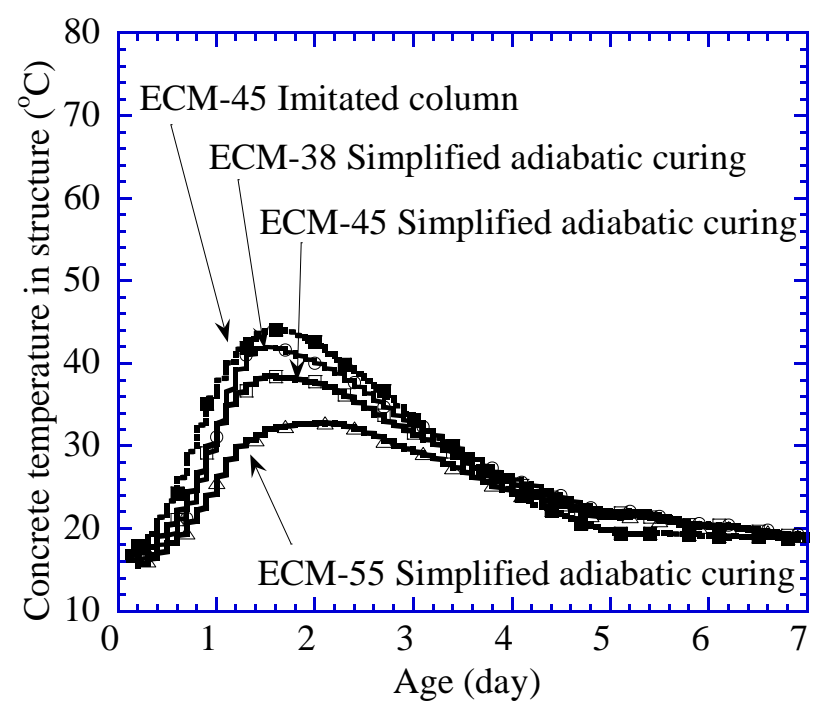

(a) Standard climatic condition

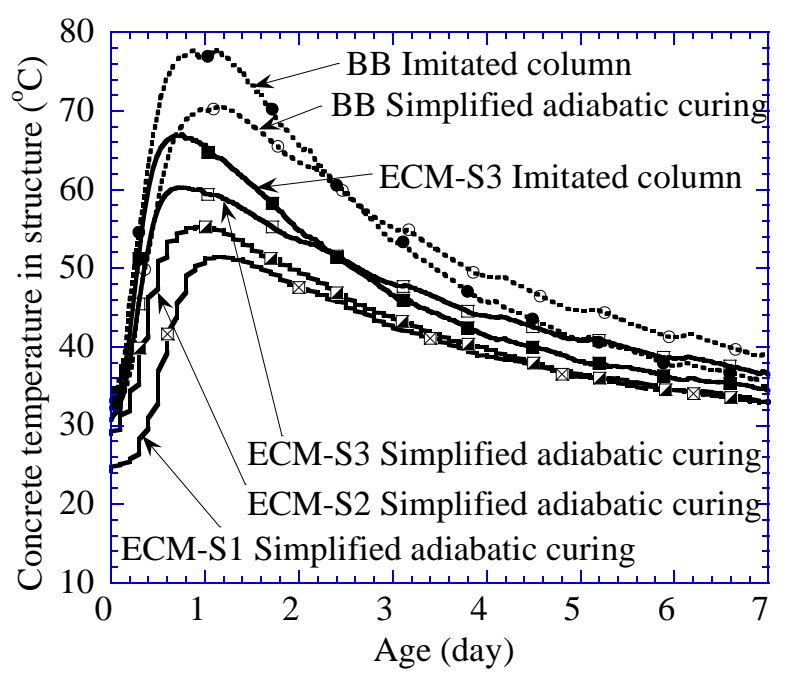

(b) Summer climatic condition

Figure 3. Temperature Histories of Concrete Structure 


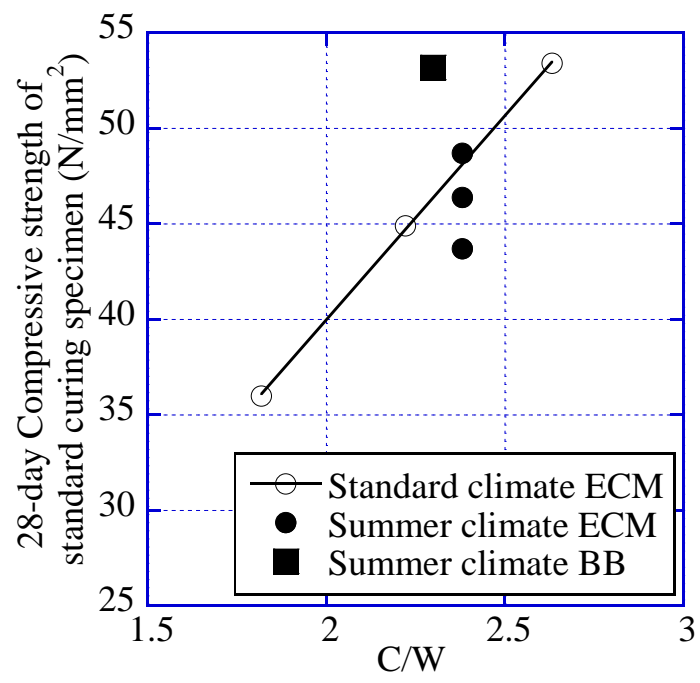

Figure 4. Effects of C/W on the Standard Curing Strength

Table 8. Fresh Properties

\begin{tabular}{|c|c|c|c|c|c|c|c|}
\hline \multirow[b]{2}{*}{$\begin{array}{l}\text { Climatic } \\
\text { condition }\end{array}$} & \multirow[b]{2}{*}{ Specimen } & \multicolumn{4}{|c|}{ Measured value } & \multirow[b]{2}{*}{$\begin{array}{l}\text { Bleeding } \\
\left(\mathrm{cm}^{3} / \mathrm{cm}^{2}\right)\end{array}$} & \multirow[b]{2}{*}{ Target } \\
\hline & & $\begin{array}{l}\text { Slump } \\
(\mathrm{cm})\end{array}$ & $\begin{array}{l}\text { Air content } \\
(\%)\end{array}$ & $\begin{array}{l}\text { Conc.temp. } \\
\left({ }^{\circ} \mathrm{C}\right)\end{array}$ & $\begin{array}{l}\text { Unit mass } \\
(\mathrm{kg} / \mathrm{L})\end{array}$ & & \\
\hline \multirow{3}{*}{ Standard } & ECM-55 & 21.5 & 4.8 & 14 & 2.27 & 0.17 & \multirow{3}{*}{$\begin{array}{l}\text { Slump: } 19 \pm 2.5 \mathrm{~cm} \text {, Air } \\
\text { content: } 4.5 \pm 1.5 \%\end{array}$} \\
\hline & ECM-45 & 21.0 & 4.9 & 14 & 2.28 & 0.12 & \\
\hline & ECM-38 & 21.0 & 5.0 & 14 & 2.29 & 0.13 & \\
\hline \multirow{4}{*}{ Summer } & ECM-S1 & 17.0 & 4.0 & 25 & - & - & \multirow{4}{*}{$\begin{array}{l}\text { Slump: } 18 \pm 2.5 \mathrm{~cm}, \text { Air } \\
\text { content: } 4.5 \pm 1.5 \%\end{array}$} \\
\hline & ECM-S2 & 20.0 & 6.0 & 29 & 2.27 & - & \\
\hline & ECM-S3 & 16.5 & 4.0 & 32 & 2.33 & - & \\
\hline & $\mathrm{BB}$ & 16.5 & 4.3 & 32 & 2.31 & - & \\
\hline
\end{tabular}

Table 9. Compressive Strength and Temperatures of Concrete under Standard Climatic Condition

\begin{tabular}{|c|c|c|c|c|c|c|c|}
\hline \multirow{2}{*}{ Notation } & \multirow{2}{*}{ Type } & \multirow{2}{*}{ Nixing temp. } & \multirow{2}{*}{ Max. Temp. } & \multicolumn{4}{|c|}{ Compressive strength $\left(\mathrm{N} / \mathrm{mm}^{2}\right)$} \\
\hline & & & & $\begin{array}{c}\text { 7- } \\
\text { day }\end{array}$ & $\begin{array}{l}28- \\
\text { day }\end{array}$ & $\begin{array}{l}56- \\
\text { day }\end{array}$ & $\begin{array}{l}91- \\
\text { day }\end{array}$ \\
\hline \multirow{2}{*}{ ECM-55 } & SAC & \multirow{2}{*}{14} & 32.8 & - & 31.4 & 35.1 & 36.7 \\
\hline & STD & & - & 26.1 & 36.0 & 40.5 & 42.1 \\
\hline \multirow{5}{*}{ ECM-45 } & SAC & \multirow{5}{*}{14} & 38.4 & - & 37.2 & 40.2 & 42.5 \\
\hline & $\begin{array}{l}\text { Core } \\
\text { Int. }\end{array}$ & & 44.1 & - & 39.3 & 43.4 & 43.7 \\
\hline & $\begin{array}{l}\text { Core } \\
\text { Ext. }\end{array}$ & & 34.0 & - & 36.5 & 37.6 & 38.3 \\
\hline & $\begin{array}{c}\text { Core } \\
\text { Av. }\end{array}$ & & 39.1 & - & 37.9 & 40.5 & 41.0 \\
\hline & STD & & - & 34.4 & 44.9 & 49.1 & 52.2 \\
\hline \multirow{2}{*}{ ECM-38 } & SAC & \multirow{2}{*}{14} & 42.0 & - & 42.9 & 45.8 & 47.2 \\
\hline & STD & & - & 41.8 & 53.4 & 58.5 & 59.8 \\
\hline
\end{tabular}


Table 10. Compressive Strength and Temperatures of Concrete under Summer Climatic Condition

\begin{tabular}{|c|c|c|c|c|c|c|c|}
\hline \multirow[b]{2}{*}{ Notation } & \multirow[b]{2}{*}{ Type } & \multirow[b]{2}{*}{ Mixing temp. } & \multirow[b]{2}{*}{ Max. Temp. } & \multicolumn{4}{|c|}{ Compressive strength $\left(\mathrm{N} / \mathrm{mm}^{2}\right)$} \\
\hline & & & & $\begin{array}{c}- \\
\text { day }\end{array}$ & $\begin{array}{l}28- \\
\text { day }\end{array}$ & $\begin{array}{l}56- \\
\text { day }\end{array}$ & $\begin{array}{l}\text { 91- } \\
\text { day }\end{array}$ \\
\hline \multirow{2}{*}{ ECM-S1 } & SAC & \multirow{2}{*}{25} & 51.4 & - & 43.5 & 46.2 & 47.8 \\
\hline & $\begin{array}{l}\text { STD } \\
\end{array}$ & & - & 35.3 & $\begin{array}{l}48.7 \\
\end{array}$ & 53.5 & 55.9 \\
\hline \multirow{2}{*}{ ECM-S2 } & SAC & \multirow{2}{*}{29} & 55.3 & - & 37.8 & 40.8 & 42.5 \\
\hline & STD & & - & 32.5 & 43.7 & 48.5 & 51.0 \\
\hline \multirow{5}{*}{ ECM-S3 } & SAC & \multirow{5}{*}{32} & 60.3 & - & 39.4 & 41.5 & 42.1 \\
\hline & $\begin{array}{l}\text { Core } \\
\text { Int. }\end{array}$ & & 67.1 & - & 41.2 & 42.6 & 43.1 \\
\hline & $\begin{array}{l}\text { Core } \\
\text { Ext. }\end{array}$ & & 53.0 & - & 40.7 & 46.5 & 45.3 \\
\hline & $\begin{array}{l}\text { Core } \\
\text { Av. }\end{array}$ & & 60.1 & - & 41.0 & 44.5 & 44.2 \\
\hline & STD & & - & 37.8 & 46.4 & 52.5 & 56.4 \\
\hline \multirow{5}{*}{ BB } & SAC & \multirow{5}{*}{32} & 70.0 & - & 46.2 & 47.4 & 48.6 \\
\hline & $\begin{array}{l}\text { Core } \\
\text { Int. }\end{array}$ & & 78.0 & - & 48.0 & 50.4 & 48.1 \\
\hline & $\begin{array}{l}\text { Core } \\
\text { Ext. }\end{array}$ & & 60.6 & - & 49.7 & 55.2 & 55.1 \\
\hline & Core Av. & & 69.3 & - & 48.9 & 52.8 & 50.7 \\
\hline & STD & & - & 39.8 & 53.2 & 59.3 & 64.2 \\
\hline
\end{tabular}

$A v .=44.1$ and $S D=3.18$ of strength of $E C M-S 1, S 2$ and $S 3$ with $S A C$ $A v \cdot=46.3$ and $S D=2.50$ of strength of ECM-S1, S2 and $S 3$ with $S T D$

Compressive strength of concrete. Test results of compressive strength of concretes are shown in tables 9 and 10. As a whole, strength of ECM concrete specimens subjected to standard curing was larger than that with simplified adiabatic curing and core specimens, showing similar tendency to those with ordinary portland cement. Effects of cement-water ratio on 28-day strength of specimen subjected to the standard curing are shown in figure 4 where a linear correlation between cement-water ratio and strength of ECM concrete is shown like that with ordinary portland cement. Strength of specimen subjected to standard curing and placed under summer climatic condition tended to be lower than that placed under normal climatic condition. Also, strength of ECM concrete was estimated to be 10 to $20 \%$ smaller than that of BB concrete at the same cement-water ratio.

Difference in compressive strength of ECM S1, S2 and S3 subjected to standard curing was approx. 5 $\mathrm{N} / \mathrm{mm}^{2}$, which may reflect the difference in maximum temperature of 10 degrees as shown in figure 3 . However, standard deviation of strength of specimens subjected to simplified adiabatic curing was 3.18 $\mathrm{N} / \mathrm{mm}^{2}$, which is not a big difference from that of the standard curing of $2.50 \mathrm{~N} / \mathrm{mm}^{2}$, implying stable strength of specimens subjected to simplified adiabatic curing (see table 10 footnote). Also, these standard deviation values are not so different from the upper limit of coefficient of variation of ready-mixed concrete, $10 \%$, hence the production of concretes was found to be stable.
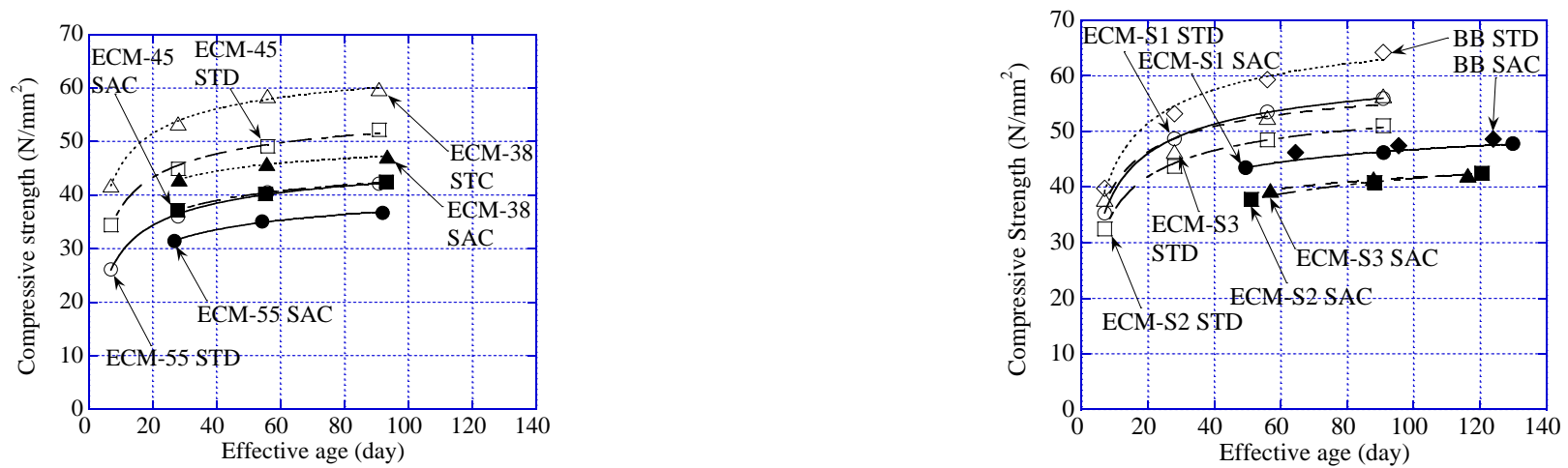

Figure 5. Approximation of Strength Development with CEB-FIP90 formula 
Table 11. Correlation Factors of CEB-FIP90 formula

\begin{tabular}{|c|c|c|c|c|c|}
\hline $\begin{array}{l}\text { Climatic } \\
\text { condition }\end{array}$ & Specimen & Type & $a_{f}$ & $S_{f}$ & $R$ \\
\hline \multirow[t]{6}{*}{ Standard } & \multirow[t]{2}{*}{ ECM-55 } & SAC & 0.88 & 0.33 & 1.00 \\
\hline & & STD & 1.01 & 0.32 & 1.00 \\
\hline & \multirow[t]{2}{*}{ ECM-45 } & SAC & 1.03 & 0.29 & 1.00 \\
\hline & & STD & 1.27 & 0.28 & 1.00 \\
\hline & \multirow[t]{2}{*}{ ECM-38 } & SAC & 1.19 & 0.21 & 1.00 \\
\hline & & STD & 1.50 & 0.24 & 1.00 \\
\hline \multirow[t]{8}{*}{ Summer } & \multirow{2}{*}{ ECM-S1 } & SAC & 1.111 & 0.32 & 1.00 \\
\hline & & STD & 1.35 & 0.31 & 1.00 \\
\hline & \multirow[t]{2}{*}{ ECM-S2 } & SAC & 0.93 & 0.45 & 1.00 \\
\hline & & STD & 1.23 & 0.30 & 1.00 \\
\hline & \multirow[t]{2}{*}{ ECM-S3 } & SAC & 1.00 & 0.32 & 0.99 \\
\hline & & STD & 1.35 & 0.27 & 0.98 \\
\hline & \multirow[t]{2}{*}{ BB } & SAC & 1.17 & 0.27 & 0.99 \\
\hline & & STD & 1.51 & 0.32 & 0.99 \\
\hline
\end{tabular}

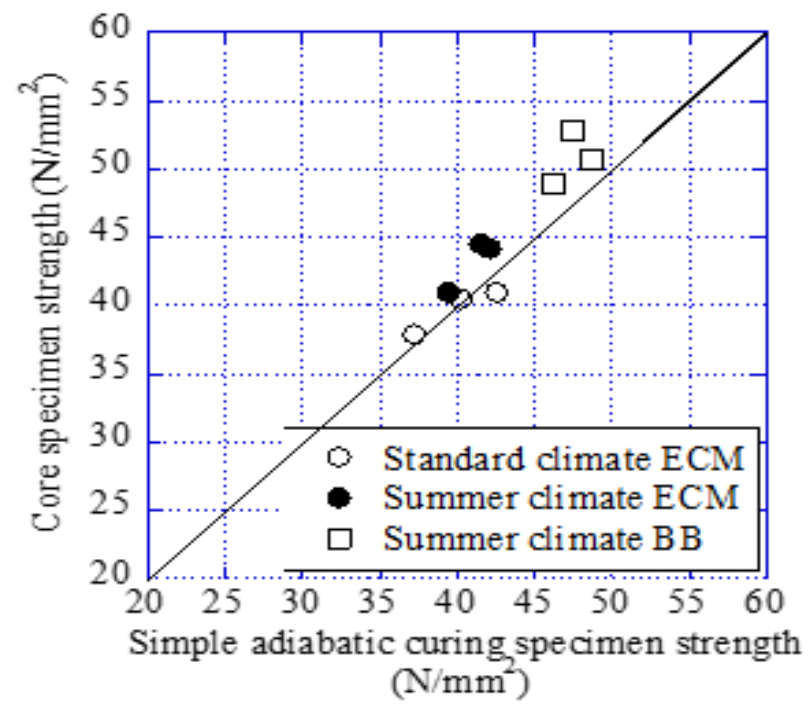

Figure 6. Strength of Simplified Adiabatic Curing Specimens and Core Specimen

\section{DISCUSSION}

Strength development curves. Strength development shown in tables 9 and 10 was examined in terms of existing formulas. The following equations (1) and (2) known as CEB-FIP formulas are adopted [CEB 1991]. Equation (1) gives effective age $t_{n}$ taking account of temperature dependency and equation (2) gives compressive strength development as a function of $t_{n}$. Least square approximation of strength data using equation (2) with a fixed final setting age of 0.4-day was performed and resulting coefficients $a_{f}$ and $S_{f}$ are shown in table 11. Relationship between measured data and approximate formulas is shown in figure 5 where strength development of ECM concrete, like the case using ordinary portland cement, could be reproduced with CEB-FIP90 approximate formula in a satisfactory precision.

To calculate the effective age, concrete temperature after measurement was substituted with daily mean temperature provided by the Meteorological Office. 
$t_{n}=\sum_{i=0}^{n} \Delta t_{i} \cdot \exp \left\{13.65-\frac{4000}{273+{ }^{T\left(\Delta t_{i}\right)} / T_{0}}\right\}$

where $t_{n}$ : effective age (day), $\Delta t_{i}$ : number of days when concrete temperature is $T\left(\Delta t_{i}\right)\left({ }^{\circ} \mathrm{C}\right)$, and $T_{0}: 1\left({ }^{\circ} \mathrm{C}\right)$.

$f_{c}\left(t_{n}\right)=\alpha_{f} \cdot f_{c}(28) \cdot \exp \left\{S_{f} \cdot\left(1-\left(\frac{28-t_{f s}}{t_{n}-t_{f s}}\right)^{0.5}\right)\right\}$

where $f_{c}\left(t_{n}\right)$ : compressive strength $\left(\mathrm{N} / \mathrm{mm}^{2}\right)$ of an effective age $t_{n}, f(28)$ : 28-day compressive strength $\left(\mathrm{N} / \mathrm{mm}^{2}\right), a_{f}$ and $S_{f}$ : coefficients to be obtained with least square approximation, and $t_{f s}$ : final setting age

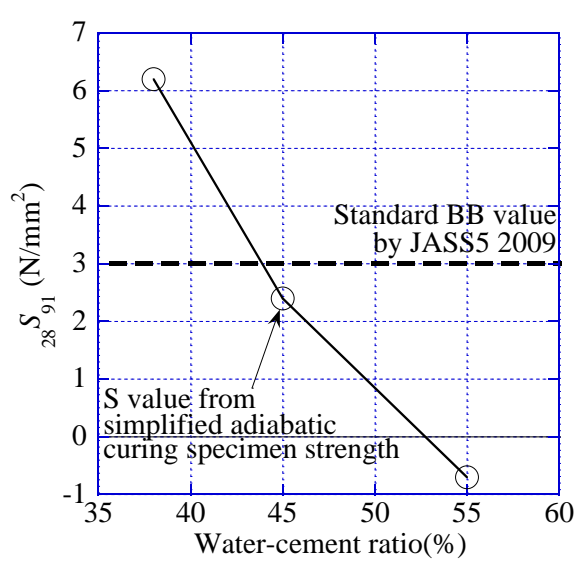

Figure 7. Effects of W/C on Concrete Strength in Structure under Standard Climatic Condition and $S$ Value (day).

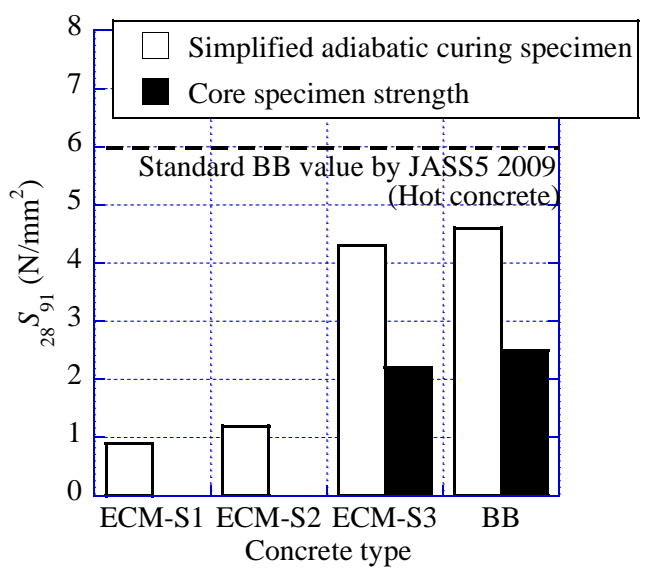

Figure 8. Comparison of $S$ Value between ECM and BB Concrete under Summer Climatic Condition

Effects of test parameters on the concrete strength in structures and $m S_{\mathbf{n}}$ values. Comparison in strength of core specimen and simplified adiabatic curing specimen, as a representing value of the strength in structure in this study, is shown in figure 6. For ECM and BB concretes in this study, core strength tended to be larger than that with simplified adiabatic curing, showing conflicting results with those obtained in normal concretes. Within the scope of this study, the cause of the contradiction is unclear, while Murakami et al. [2003] compared strengths of core specimen and specimen with simplified adiabatic curing at high strength ranges and similar tendency was confirmed when blast furnace slag type B cement was used unlike the cases of ordinary portland cement and low heat portland cement. If reproducible, it may be advantageous that specimen with simplified adiabatic curing could replace the core specimen to obtain $S_{\mathrm{f}}$ value in safer and inexpensive manners.

Effects of water-cement ratio on ${ }_{28} S_{91}$ value at standard climatic condition are shown in figure 7 . The ${ }_{28} S_{91}$ value refers to difference in strength between 28-day standard curing specimen and core specimen or simplified adiabatic curing specimen. It is observed that the ${ }_{28} S_{91}$ values of simplified adiabatic curing specimen tend to increase with a decrease in water-cement ratio. Also, normal ${ }_{28} S_{91}$ value of concrete with blast furnace slag cement type B specified in JASS5-2009 under standard climatic condition is $3 \mathrm{~N} / \mathrm{mm}^{2}$ and larger than that of ECM concrete with a water-cement ratio lower than 0.45.

The ${ }_{28} S_{91}$ values under summer climatic condition are shown in figure 8 . The standard value of ${ }_{28} S_{91}$ for concrete with blast furnace slag cement type B under hot climatic condition as shown in JASS5-2009 is 6 $\mathrm{N} / \mathrm{mm}^{2}$, which is larger than that of ECM concrete in this study. 


\section{CONCLUSION}

In this study, structural concrete strength of ECM concrete, with high-volume blast furnace slag, was experimentally investigated, and major findings are as follows.

(1) Stable manufacturing of ECM concrete in summer was attained because the variation in strength of specimens subjected to both standard curing and simplified adiabatic curing were within a range of the standard value.

(2) Among ECM concrete specimens tested for strength in structure, core concrete strength from the imitated column tended to be larger than that of specimens with simplified adiabatic curing.

(3) Strength development of ECM concrete specimens subjected to both standard curing and simplified adiabatic curing showed good agreement with a prediction using CEB-FIP90 formula in a satisfactory precision.

(4) Strength of ECM concrete in structure under standard climatic condition was smaller than that of specimen subjected to the standard curing similar to the case of normal concrete, and the strength correction value ${ }_{28} S_{91}$ representing the difference in strength tended to increase with a decrease in watercement ratio.

(5) Temperatures inside of ECM concrete of the imitated column placed in summer went up approx. $70^{\circ} \mathrm{C}$, while it was 10 degree lower than concrete temperature with blast furnace slag cement type B showing a possible advantage in thermal cracking control.

(6) At a water-cement ratio larger than 0.45 , strength correction value ${ }_{28} S_{91}$ of ECM concrete in structure under standard climatic condition was equal to or lower than the standard value of concrete with blast furnace slag cement type B of JASS5.

(7) Strength correction value ${ }_{28} S_{91}$ of ECM concrete in structure under summer climatic condition was nearly equal to that of concrete with blast furnace slag cement type B and was smaller than that of the standard value of JASS5.

\section{ACKNOWLEDGEMENT}

This work was supported by JSPS KAKENHI Grant Number $15 \mathrm{H} 04084$.

\section{REFERENCES}

Architectural Institute of Japan-AIJ (2009). "Standard Specification for Building Constructions and Commentary, JASS 5 Reinforced Concrete Construction." (in Japanese)

Comité Euro-International du Béton (1991). “CEB-FIP Model Code 1990.” Thomas Telford.

Japan Concrete Institute-JCI (2008). "Concrete Innovation in an Age of Environment." Report of the Technical Committee of Environmental Performance of Concrete Structures. (in Japanese)

Japan Concrete Institute-JCI (2010). "Report of the Technical Committee on Shrinkage Cracking Reduction and Durability Enhancement from a viewpoint of Admixture." (in Japanese)

Murakami, T., Tamura, H., Masuda, Y., Matsufuji, Y., Tanigawa, Y., and Ohno, Y. (2003). "Performance Evaluation of High-Dtrength Concrete - Standard Water-Cement Ratio Assuring Concrete Strength in Structures." GBRC, (114), 2-13. (in Japanese)

Sakata, N., Hayashi, D., Sakai, G., and Miyagawa, T. (2010). "Study of RCD Concrete with High Volume 
Ground Blast Furnace Slag." Proceedings of Japan Concrete Institute, 32(1), 191-196. (in Japanese)

Yonezawa, T., Sakai, E., Koibuchi, K., Kinoshita, M., and Kamano, H. (2010). "Energy $/ \mathrm{CO}_{2}$ Minimum (ECM) Cement Concrete System.” Concrete Journal, 48(9), 69-73. (in Japanese) 